GHANA JOURNAL OF DEPARTMENT OF HEALTH, PHYSICAL EDUCATION AND RECREATION, SPORTS AND DANCE (GJOHPERSD)

Volume 7 \& 8, Year 2014 \& 2015

A JOURNAL OF THE DEPARTMENT OF HEALTH, PHYSICAL EDUCATION AND RECREATION (HPER)

UNIVERSITY OF CAPE COAST

GHANA, WEST AFRICA 


\title{
DIFFERENCES IN BODY ANTHROPOMETRY BETWEEN COMPETITIVELY EFFICIENT AND LESS EFFICIENT JUNIOR MALE HANDBALL PLAYERS
}

\author{
Adodo, S. M. \& Agwubike, E. O \\ Institute of Education \\ University of Benin \\ Benin City, Nigeria \\ e-mail:samado2g4@gmail.com,samuel.adodo@uniben.edu \\ Department of Human Kinetics and Sports Science \\ University of Benin \\ Benin City, Nigeria \\ e-mail: ellydike70@gmail.com
}

\begin{abstract}
This study was carried out to determine if differences existed in anthropometric and body composition characteristics between competitively efficient (above average) and less efficient (average) junior male handball players. A total of 106 junior male handball players participated in this study. The players were divided into two playing quality or performance groups of above average or (competitively efficient) $(n=26)$ and average or competitively less efficient $(n=80)$ levels. A combination of individual players' quality as determined subjectively by a consortium of national handball coaches and team ranking achieved at a championship were used to achieve this purpose. 22 anthropometric attributes were measured for each subject. Similarly, 6 body composition variables were estimated. The results showed that the above average players were better endowed morphologically than the average players particularly in the Longitudinal Skeleton Dimensionality (LSD), Transverse Skeleton Dimensionality (TSD) and Absolute Voluminosity of the Body (AVB) dimensions. The junior male players at both levels of performance were relatively homogenous in the Subcutaneous Fatty Tissue (SFT). However, the
\end{abstract}


Differences in Body Anthropometry between Competitively efficient and less Efficient Junior male Handball Players

average level players had significantly lower supra spinale skinfold measure $(t=2.57, P<0.011)$ than the above average level players. Derived body composition measures of skeletal mass $(t=5.80 ; p<0.000) ;$ muscle mass $(t=4.87 ; p<0.000)$; and fat free mass $(t=6.59 ; p<0.000)$ were statistically significant in favour of the above average players. The mean $(S D)$ somatotype of all the players $(2.04[0.5] ; 3.13[1.0] ; 3.6[1.1])$ were statistically significant. Similarly, the somatotype classification of mesoectomorphic (mesomorphic ectomorph) characterised both levels of players (above average - 2.1[0.4], 2.85[0.8], 3.85[0.8] versus average - 2.01(0.5), 3.23[1.1], 3.54[1.2]) as there were no significant differences in these somatotype components. Results of the study demonstrated that the competitively efficient junior male handball players were significantly differentiated as possessing superior anthropometric characteristics compared to the less efficient junior male handball players.

Key words: Anthropometry, body composition, handball players, somatotype, morphological dimension 


\section{Introduction}

Team handball was introduced into Nigeria in 1972 in preparation for the hosting of the $2^{\text {nd }}$ All African Games (Handball Federation of Nigeria [HFN], 2000). Handball was listed as one of the events for competition for the first time in the history of All Africa Games. From that point, according to Adodo (2014), the game developed so fast and enjoyed a nationwide popularity perhaps next to soccer. This culminated in several successful high points in Nigeria's handball history. According to HFN (2000), Nigeria was the first African handball nation to win the African junior women handball championship for keeps after winning the 1986, 1988 and 1990 editions of the championship. Nigeria also hosted the $7^{\text {th }}$ World Junior Ladies Handball Championships in Bauchi in 1989, becoming the first African country to host a world handball championship. It is also on the record of HFN that Nigeria has won the African Nation's cup in handball in the female category. Furthermore, the Nigerian Senior female team was indeed the first team sport apart from football, to represent Nigeria at the 1992 Barcelona Olympic Games. The senior national male team, also participated in the 1999 world male handball championship in Egypt, becoming the first of such a team from a black nation to participate at that level.

Overtime, the fortune of the game of handball in Nigeria began to record decline in spite of the initial successes that brought the game to enviable limelight and status in the eighties (Dauda, 2010). In this regard, sports professionals, administrators, researchers and other stake holders have related the causes of decline in handball performance overtime mostly to organisational problems. However, added to this is the fact that the need to identify, select and train young players who possess or have the potential to develop certain anthropometric, motor, physiological and other parameters of performance successes were often ignored (Adodo, 2014; Cavala, Rogulj, Srhoj, Srhoj \& Katic, 2008). The implications of this, in practice, are that athletes suitability to compete efficiently at a particular level may depend on the 
Differences in Body Anthropometry between Competitively efficient and less Efficient Junior male Handball Players

possession of these and other predictors of performance quality (Taborsky, 2007; Zapartidis et al., 2009).

Team success in modern handball game seems to depend on a number of factors that includes, among others, anthropometric characteristics, technical and tactical elements of the game (Srhoj, Marinovic \& Rogulj, 2002). The anthropometric and body composition of players however, appear to have a fairly important role in determining performance at the highest level within team handball (Buchheit, Laursen, Kuhnle, Ruch, Renauch \& Ahmaidi, 2009). Thus, practitioners and scientists have continuously sought to identify anthropometric and body composition characteristics that distinguish high and low class players (Granados, Izquierdo, Ibanez, Bonnabau \& Gorostiaga, 2007; Gorostiaga, Granados, Ibanez, Gonzalez-Badillo \& Izquierdo, 2006).

A number of studies in various team sports have provided relevant information regarding anthropometric characteristics and performance of players classified as competitively efficient (above average), and less efficient (average). For example, anthropometric characteristics of players in ball games such as soccer (Janssens, Van - Renterghan, Bourgeois \& Vrijens, 2000); hockey (Elferink Gemser, Visschar, Lemmink \& Mulder, 2004); basketball (Cook, Kiss, Khan, Purdan \& Webster, 2004); volleyball (Gabbett \& Georgieff, 2007: Duncan, Woodfield \& ai - Naskeeb, 2006); handball (Zapartidis et al, 2009; Hasan et al, 2007) and others are well documented. Specifically, Hirata (1979) and Khosla (1993) as cited in Hasan et al (2007) have demonstrated that the handball players in the medal winning teams possess significantly superior anthropometric qualities than the others, thus suggesting how important these qualities are to playing handball successfully. However, a few studies have also showed that the impact of anthropometrics does not always transfer to improved performance (Gabbett \& Georgieff, 2007). In this regard, Roschel, Baptista, Monteiro et al (2009) showed that there is no significant difference in anthropometric data between winners and defeated karate players.

These studies have provided important information on the anthropometric and body composition characteristics of elite and 4 A Journal of the Department of Health, Physical Education and Recreation 
sub - elite players of other sports and of handball at the global level. Although these studies have compared anthropometric characteristics across age - categories and skill levels in youth sports, no known study has directly examined how anthropometric and body composition characteristics have contributed to playing quality within a developmental and representative group of junior male handball players in Nigeria. It is therefore difficult, based on research to date, to assume which anthropometric and body composition variables are able to discriminate between more homogenous (similar age and skill level) samples in a given sport context.

Assuming that handball players can be discriminated along playing quality (above average and average) in anthropometric and body composition dimensions, this study was carried out to determine if differences existed in anthropometric and body composition characteristics between competitively efficient (above average) and less efficient (average) junior male handball players. So far, it is not clear what the empirical situation has been as to identifying the anthropometric and body composition characteristics that discriminate playing quality of Nigerian junior male handball players. Determining these characteristics could become very important for predicting the young players' path to excellence in performance as well as point out talents for selection, training and development. On the basis of this, an hypothesis of no significant difference in the anthropometric and body composition characteristics of Nigerian junior male handball players of above average and average levels of playing quality was tested in this study:

There is.

\section{Methods}

\section{Sample}

The sample was made up of 106 junior male handball players from 7 out of the 15 states under 18 (U18) male handball teams that competed in the National male handball championship for the under 18 years age group. These state teams were 
Differences in Body Anthropometry between Competitively efficient and less Efficient Junior male Handball Players

deliberately selected on the basis of their ranking/performance at the championships. Specifically, two top, three middle-order and two low-ranking teams eventually participated in the study. The purpose was to separate the subjects into two playing quality or performance groups of above average and average players.

A combination of individual player's quality as determined subjectively by a consortium of national handball coaches and team ranking in the championships were used to achieve this purpose. Players who were considered good enough to be invited to the national U18 team camp in preparation for a major subregional youth handball championship; and players in teams that attained the highest positions $\left(1^{\text {st }}, 2^{\text {nd }}\right)$ in the final championship classifications were considered above average $(n=26)$ in playing quality. Other players who did not make the coaches' list and did not attain the highest positions in the championship were grouped as average $(n=80)$ in playing quality.

\section{Variables}

Anthropometric attributes, spread across the four presumed morphological dimensions of Longitudinal Skeleton Dimension (LSD), Transverse Skeleton Dimension (TSD), Absolute Voluminosity of Body (AVB), and Subcutaneous Fatty Tissue (SFT) (Cavala et al, 2008) were measured (Table 1). The Body Composition Variables (Table 2) were estimated.

The Longitudinal Skeleton Dimension of height was measured on a stadiometer (GPM, Serifex, Inc., East Rutherford, New Jersey), while the steel anthropometry tape (Lufkin W606PM, Rosscraft, Surrey, UK) was used to measure arm span. Arm length (acromiale - radiale) and hand length (midstylion - dactylion) were measured using Campbell 20 large sliding caliper with A-P branches (Rosscraft, Surrrey, UK) respectively. The Martin - type Siber-Hegner anthropometer (GPM, Serifex, East Rutherford, USA) was used to measure leg or tibial length (tibial - mediale).

All circumference measures (TSD) were taken using steel anthropometry tape (Lufkin W606PM, Rosscraft, Surrey, UK) The Campbell 10(18) small sliding caliper was used to measure the 
diameter or girth of all the AVB variables. Body weight, however, was measured with OMRON BF 400 body fat monitor. The skinfold thickness of identified SFT sites were determined using calibrated Harpenden skinfold calipers. The body composition variables of skeletal, muscle and fat free masses as well as somatotype were estimated using procedures recommended by International Society for the Advancement of Kinanthropometry (ISAK) (2001). The obtained values for the lengths, breadth and girths were within the established criteria of $0.2 \mathrm{~cm}$ tolerance level; while the skinfold measurements were within $5 \%$ tolerance level as recommended by Marfell-Jones (2003).

These instruments were previously validated in different research settings and populations (Ingebrigsten \& Jefferys, 2012; Cavala et al, 2008; Katic, Grgantov \& Jurko, 2006). Sufficiently high intra - class correlation coefficient of $0.98,0.98,0.95,0.96$ and 0.96 with corresponding technical error of measurement (TEM) of $0.2 \%, 0.3 \%, 0.5 \%, 0.3 \%$ and $0.2 \%$ were obtained for the LSD, TSD, AVB, SFT variables respectively. These indicate acceptable reliability based on established criteria by Hopkins (2000).

\section{Data collection}

All anthropometric measurements were taken by the same investigator and three trained assistants on the handball court for the three days, at the same specified time and completed in the same order. Measurements were taken on the players' dominant side so that differences caused by continuous use of the dominant side of the body in competition and training do not invalidate the measurement results (Srhoj et al, 2002). Each participant was informed of the procedures and provided signed written consents in accordance with the University of Benin, Nigeria research ethics procedures. Participants were required to appear in minimum clothing and "landmarked" thereafter. 
Differences in Body Anthropometry between Competitively efficient and less Efficient Junior male Handball Players

\section{Statistical analysis}

Mean and standard deviation (SD) scores were calculated for all dependent variables (anthropometric attributes) with level of playing quality (above average and average) acting as the independent variable. The independent $t$ - test analysis of difference was used to determine differences in anthropometric attributes between the above average and average players. The statistical package for social sciences (SPSS) IBM version 20 was used for all analysis with significance set as $\mathrm{p}<0.05$.

\section{Results}

The descriptive and inferential statistics of the difference in anthropometric and body composition characteristics between the above average players (AAP) and the average players (AVP) are presented in Tables 1 and 2. The consortium of coaches considered 26 players, representing $25 \%$ of the total sample as above average in playing quality, while 80 players or $75 \%$ of the total sample were considered average in playing quality.

Generally, the AAP had larger overall mean scores in almost all the anthropometric variables under consideration than the AVP; they were particularly taller $(\mathrm{t}=7.62 ; \mathrm{p}<0.000)$ and heavier $(\mathrm{t}=6.27 ; \mathrm{p}<0.000)$ than the AVP. In the longitudinal skeleton dimensions of anthropometrics, the AAP were better endowed than the AVP in arm length $(\mathrm{t}=4.42 ; \mathrm{p}<0.000)$; hand length $(\mathrm{t}=2.33 ; \mathrm{p}<0.028)$; leg length $(\mathrm{t}=5.38, \mathrm{p}<0.000)$ and arm span $(t=4.58, \quad p<0.000)$. Significant differences in three anthropometric transverse skeleton dimensions (TSD) of handbreadth $(\mathrm{t}=3.32, \mathrm{p}<0.001)$; wrist breadth $(\mathrm{t}=3.57, \mathrm{p}<0.001)$; and femur breadth $(\mathrm{t}=5.00 ; \mathrm{p}<0.000)$ were also recorded in favour of AAP. However, there were no significant differences in humerus breadth $(\mathrm{t}=1.06, \mathrm{p}<0.056)$. 
Table 1: Descriptive statistics and $t$ - test analyses of differences in anthropometric characteristics mean scores according to playing quality

\begin{tabular}{|c|c|c|c|c|c|}
\hline \multirow[b]{2}{*}{ Variables } & \multirow[b]{2}{*}{$\begin{array}{l}\text { All } \\
\text { players } \\
\mathrm{N}=106 \\
\text { Mean } \\
\text { (SD) }\end{array}$} & \multicolumn{2}{|l|}{$\begin{array}{l}\text { Playing } \\
\text { Quality }\end{array}$} & \multirow[b]{2}{*}{$\mathbf{t}$} & \multirow[b]{2}{*}{$\begin{array}{l}\text { p- } \\
\text { value }\end{array}$} \\
\hline & & $\begin{array}{l}\text { Above } \\
\text { Average } \\
n=26 \\
\text { Mean } \\
\text { (SD) } \\
\end{array}$ & $\begin{array}{l}\text { Average } \\
\mathrm{n}=80 \\
\text { Mean } \\
\text { (SD) }\end{array}$ & & \\
\hline $\begin{array}{l}\text { Body height } \\
\text { (cm) }\end{array}$ & $\begin{array}{l}173.37(7 \\
3)\end{array}$ & $\begin{array}{l}181.02(5 . \\
4)\end{array}$ & $\begin{array}{c}170.88( \\
6.9)\end{array}$ & 7.62 & 0.000 \\
\hline $\begin{array}{l}\text { Arm length } \\
(\mathrm{cm})\end{array}$ & $\begin{array}{l}31.79(2.2 \\
)\end{array}$ & $\begin{array}{l}33.33(2.2 \\
)\end{array}$ & $\begin{array}{l}31.29 \\
(2.0)\end{array}$ & 4.41 & $\underset{*}{0.000}$ \\
\hline $\begin{array}{l}\text { Hand length } \\
(\mathrm{cm})\end{array}$ & $\begin{array}{l}20.50(1.9 \\
)\end{array}$ & $\begin{array}{c}21.21(1.1 \\
)\end{array}$ & $\begin{array}{c}20.27 \\
(2.1)\end{array}$ & 2.23 & 0.028 \\
\hline Leg length $(\mathrm{cm})$ & $\begin{array}{l}39.46(2.6 \\
)\end{array}$ & $\begin{array}{c}41.60(2.9 \\
)\end{array}$ & $\begin{array}{l}38.77 \\
(2.1)\end{array}$ & 5.38 & 0.000 \\
\hline \multirow[t]{2}{*}{ Arm span $(\mathrm{cm})$} & $\begin{array}{l}184.38(9 \\
6)\end{array}$ & $\begin{array}{l}191.21(9 . \\
1)\end{array}$ & $\begin{array}{c}182.16( \\
8.7) \\
\end{array}$ & 4.58 & 0.000 \\
\hline & \multicolumn{3}{|c|}{$\begin{array}{l}\text { Transverse Skeleton } \\
\text { Dimensionality (TSD) }\end{array}$} & & \\
\hline $\begin{array}{l}\text { Hand breadth } \\
(\mathrm{cm})\end{array}$ & $\begin{array}{r}8.25 \\
(0.5)\end{array}$ & $8.50(0.4)$ & $\begin{array}{r}8.17 \\
(0.5)\end{array}$ & 3.32 & 0.001 \\
\hline $\begin{array}{l}\text { Wrist breadth } \\
(\mathrm{cm})\end{array}$ & $\begin{array}{r}5.50 \\
(0.5)\end{array}$ & $5.79(0.6)$ & $\begin{array}{r}5.41 \\
(0.4)\end{array}$ & 3.57 & 0.001 \\
\hline $\begin{array}{l}\text { Humerus } \\
\text { breadth }(\mathrm{cm})\end{array}$ & $\begin{array}{r}6.20 \\
(0.5)\end{array}$ & $6.28(0.4)$ & $\begin{array}{r}6.17 \\
(0.5)\end{array}$ & 1.06 & 0.293 \\
\hline $\begin{array}{l}\text { Femur breadth } \\
(\mathrm{cm})\end{array}$ & $\begin{array}{r}8.52 \\
(0.5)\end{array}$ & $8.87(0.4)$ & $\begin{array}{r}8.40 \\
(0.4)\end{array}$ & 5.00 & $\underset{*}{0.000}$ \\
\hline $\begin{array}{l}\text { Ankle breadth } \\
(\mathrm{cm})\end{array}$ & $\begin{array}{r}6.65 \\
(0.5) \\
\end{array}$ & $6.79(0.4)$ & $\begin{array}{r}6.60 \\
(0.5) \\
\end{array}$ & 1.94 & 0.055 \\
\hline & \multicolumn{3}{|c|}{$\begin{array}{l}\text { Absolute Voluminosity of } \\
\text { Body (AVB) }\end{array}$} & & \\
\hline
\end{tabular}


Differences in Body Anthropometry between Competitively efficient and less Efficient Junior male Handball Players

\begin{tabular}{|c|c|c|c|c|c|}
\hline Body weight & 61.86 & 68.82 & 59.60 & 6.27 & 0.000 \\
\hline$(\mathrm{kg})$ & (7.6) & (7.1) & (6.3) & & \\
\hline Arm girth & 26.74 & 27.77 & 26.40 & 3.41 & 0.001 \\
\hline$(\mathrm{R})(\mathrm{cm})^{+}$ & (1.9) & (1.6) & (1.9) & & \\
\hline $\begin{array}{l}\text { Arm girth }(\mathrm{F}) \\
(\mathrm{cm})^{++}\end{array}$ & $\begin{array}{l}29.78 \\
(2.3)\end{array}$ & $\begin{array}{l}31.23 \\
(2.1)\end{array}$ & $\begin{array}{l}29.31 \\
(2.2)\end{array}$ & 3.99 & $\underset{*}{0.000}$ \\
\hline $\begin{array}{l}\text { Chest girth } \\
(\mathrm{cm})\end{array}$ & $\begin{array}{l}85.59 \\
(4.6)\end{array}$ & $\begin{array}{l}89.31 \\
(4.3)\end{array}$ & $\begin{array}{l}84.39 \\
(3.9)\end{array}$ & 5.38 & $\begin{array}{l}0.000 \\
*\end{array}$ \\
\hline $\begin{array}{l}\text { Mid-thigh girth } \\
(\mathrm{cm})\end{array}$ & $\begin{array}{r}47.57 \\
(4.1)\end{array}$ & $\begin{array}{c}49.39 \\
(3.9)\end{array}$ & $\begin{array}{l}46.98 \\
(3.9)\end{array}$ & 2.69 & 0.000 \\
\hline Calf girth $(\mathrm{cm})$ & $\begin{array}{l}34.01 \\
(2.3)\end{array}$ & $\begin{array}{l}34.92 \\
(2.4)\end{array}$ & $\begin{array}{l}33.72 \\
(2.2)\end{array}$ & 2.34 & 0.021 \\
\hline \multicolumn{6}{|c|}{$\begin{array}{l}\text { Subcutaneous Fatty Tissue } \\
\text { (SFT) }\end{array}$} \\
\hline $\begin{array}{l}\text { Triceps SF } \\
(\mathrm{mm})\end{array}$ & $\begin{array}{r}6.27 \\
(1.8)\end{array}$ & $6.42(1.4)$ & $\begin{array}{r}6.25 \\
(1.9)\end{array}$ & 0.48 & 0.631 \\
\hline $\begin{array}{l}\text { Subscapular } \\
(\mathrm{mm})\end{array}$ & $\begin{array}{l}8.50 \\
(2.2)\end{array}$ & $9.42(2.3)$ & $\begin{array}{l}8.20 \\
(2.1)\end{array}$ & 2.57 & 0.011 \\
\hline $\begin{array}{l}\text { Supraspiniale } \\
\text { SF }(\mathrm{mm})\end{array}$ & $\begin{array}{r}6.31 \\
(1.4)\end{array}$ & $6.69(1.8)$ & $\begin{array}{r}6.19 \\
(1.3)\end{array}$ & 1.56 & 0.122 \\
\hline $\begin{array}{l}\text { Abdominal SF } \\
(\mathrm{mm})\end{array}$ & $\begin{array}{l}8.31 \\
(2.2)\end{array}$ & $8.81(2.4)$ & $\begin{array}{l}8.15 \\
(2.1)\end{array}$ & 1.34 & 0.184 \\
\hline $\begin{array}{l}\text { Front of thigh } \\
\mathrm{SF}(\mathrm{mm})\end{array}$ & $\begin{array}{l}7.58 \\
(2.3)\end{array}$ & $7.81(2.3)$ & $\begin{array}{l}7.51 \\
(2.3)\end{array}$ & 0.57 & 0.572 \\
\hline $\begin{array}{l}\text { Medical calf SF } \\
(\mathrm{mm})\end{array}$ & $\begin{array}{r}6.64 \\
(1.9) \\
\end{array}$ & $6.89(2.4)$ & $\begin{array}{r}6.56 \\
(1.7) \\
\end{array}$ & 0.74 & 0.458 \\
\hline
\end{tabular}

Keys: $*$ significant at $0.05 ; \mathrm{cm}=$ centimeter; $\mathrm{Kg}=$ Kilogram; $+=$ relaxed arm girth; $++=$ flexed arm girth $; \mathrm{kg} / \mathrm{m}^{2}=$ kilogram per meter; $\mathrm{SF}=$ skinfold 
Table 2: Descriptive statistics and $t$ - test analyses of difference in body composition characteristics according to playing quality

\begin{tabular}{|c|c|c|c|c|c|}
\hline \multirow[b]{2}{*}{ Variables } & \multirow[b]{2}{*}{$\begin{array}{l}\text { All } \\
\text { players } \\
\text { N = 106 } \\
\text { Mean } \\
\text { (SD) }\end{array}$} & \multicolumn{2}{|c|}{$\begin{array}{l}\text { Playing } \\
\text { Quality }\end{array}$} & \multirow[b]{2}{*}{$\mathbf{t}$} & \multirow[b]{2}{*}{$\begin{array}{l}p- \\
\text { value }\end{array}$} \\
\hline & & $\begin{array}{l}\text { Abov } \\
\text { e } \\
\text { Avera } \\
\text { ge } \\
\text { n= 26 } \\
\text { Mean } \\
\text { (SD) } \\
\end{array}$ & $\begin{array}{l}\text { Aver } \\
\text { age } \\
n= \\
80 \\
\text { Mean } \\
\text { (SD) }\end{array}$ & & \\
\hline Skeletal mass $(\mathrm{kg})$ & $\begin{array}{c}7.54 \\
(0.9)\end{array}$ & $\begin{array}{r}8.36 \\
(0.8)\end{array}$ & $\begin{array}{r}7.27 \\
(0.9)\end{array}$ & 5.80 & $0.000^{*}$ \\
\hline Muscle mass (kg) & $\begin{array}{c}29.44 \\
(2.9)\end{array}$ & $\begin{array}{c}31.60 \\
(2.6)\end{array}$ & $\begin{array}{r}28.73 \\
(2.6)\end{array}$ & 4.87 & $0.000^{*}$ \\
\hline $\begin{array}{l}\text { Fat free mass } \\
\left(\mathrm{kg} / \mathrm{m}^{0.14}\right)\end{array}$ & $\begin{array}{l}54.87 \\
(6.0)\end{array}$ & $\begin{array}{r}60.57 \\
(5.1)\end{array}$ & $\begin{array}{c}53.01 \\
(5.1)\end{array}$ & 6.59 & $0.000^{*}$ \\
\hline $\begin{array}{l}\text { Body mass index } \\
\left(\mathrm{kg} / \mathrm{m}^{2}\right)\end{array}$ & $\begin{array}{l}20.45 \\
(1.9)\end{array}$ & $\begin{array}{r}20.90 \\
(1.5)\end{array}$ & $\begin{array}{r}20.30 \\
(2.0)\end{array}$ & $\begin{array}{l}1.41 \\
1.91\end{array}$ & $\begin{array}{l}0.162 \\
0.059\end{array}$ \\
\hline$\%$ Body fat & \multicolumn{2}{|c|}{$\begin{array}{l}10.76(3.5) \\
11.89(3.6)\end{array}$} & $\begin{array}{l}10.39 \\
(3.5)\end{array}$ & & \\
\hline Endomorphy & \multicolumn{2}{|c|}{$\begin{array}{l}2.04(0.5) \\
2.12(0.4)\end{array}$} & $\begin{array}{l}2.01 \\
(0.5)\end{array}$ & 0.88 & 0.379 \\
\hline Mesomorphy & $\begin{array}{r}3.13 \\
(1.0)\end{array}$ & $\begin{array}{r}2.85 \\
(0.8)\end{array}$ & $\begin{array}{r}3.23 \\
(1.1)\end{array}$ & 1.67 & 0.098 \\
\hline Ectomorphy & $\begin{array}{l}3.61 \\
(1.1)\end{array}$ & $\begin{array}{l}3.85 \\
(0.8)\end{array}$ & $\begin{array}{l}3.54 \\
(1.2)\end{array}$ & 1.27 & 0.208 \\
\hline
\end{tabular}

Keys:*significant at $0.05 ; \mathrm{cm}=$ centimeter; $\mathrm{Kg}=$ Kilogram; $\mathrm{kg} / \mathrm{m}^{2}$ $=$ kilogram per meter; $\mathrm{SF}=$ skinfold.

The mean differences obtained for the absolute voluminosity of body (AVB) anthropometric parameters in relaxed arm girth $(\mathrm{t}=3.41, \mathrm{p}<0.000)$, flexed arm girth $(\mathrm{t}=3.99, \mathrm{p}<0.000)$; 
Differences in Body Anthropometry between Competitively efficient and less Efficient Junior male Handball Players

chest girth $(\mathrm{t}=6.38, \mathrm{p}<0.000)$; mid - thigh girth $(\mathrm{t}=2.69, \mathrm{p}<0.000)$; and calf girth $(\mathrm{t}=6.38, \mathrm{p}<0.000)$ were statistically significant. In the area of subcutaneous fatty tissue (SFT), the mean difference in the subscapular skinfold $(\mathrm{t}=2.51, \mathrm{p}<0.011)$ was the only recorded statistically significant result. Derived body composition measures of skeletal mass $(\mathrm{t}=5.80 ; \mathrm{p}<0.000)$; muscle mass $(\mathrm{t}=4.87 ; \mathrm{p}<0.000)$; and fat free mass $(\mathrm{t}=6.59 ; \mathrm{p}<0.000)$ were statistically significant. The somatotype classification of mesomorphic ectomorph characterised both levels of players as there were no significant differences in the somatotype components. These results showed that the AAP were better endowed morphologically than the AVP particularly in the longitudinal skeleton and absolute voluminosity of body dimensions.

\section{Discussion}

Cavala et al (2008) in a study of elite female handball players reported that the above average players were sufficiently discriminated from the average players in all anthropometric variables except in height, arm span and leg length. The study measured differences in anthropometric variables in junior male handball players classified as competitively efficient (above average) and less efficient (average). The results of the study evidently showed that the above average players were superior to the average players in most of the anthropometric and body composition variables. A comparison of the results obtained in this study with those reported for younger and older top level, male and female handball players revealed proportionally identical values in large number of anthropometric variables. For example, Mohamed et al (2009) found significant differences in most anthropometric attributes in their elite and non-elite under 16 handball players. Similarly, Hasan et al (2007), in a related study where players were divided into two groups of successful and unsuccessful teams on the basis of performance at a championship, reported that the more successful teams had better endowed players than in the less successful teams in terms of anthropometric characteristics. This goes to suggest that these attributes underpin playing success in handball.

12 A Journal of the Department of Health, Physical Education and Recreation 
However, when comparing the obtained anthropometric and body composition characteristics of handball players to the results reported for athletes from other sports, certain similarities and differences may be observed. Roschel and Colleagues (2009) showed that there were no significant differences in anthropometric measures between winner and defeated karate players. Gabbett et al (2007) and Elferink-Gemser et al (2004) in studies examining homogenous (junior elite and sub-elite) samples of volleyball and field hockey players respectively, also found no significant differences in anthropometric characteristics. Similarly, Nicolaire, Correa and Böhme (2010) found the total and corrected thigh circumferences as the only anthropometric variables with statistically significant group differences (elite vs. non-elite). In specific terms, the results of the present study showed that the above average players achieved higher values than the average players in all of the LSD and AVB anthropometric features. Taborsky (2007) identified features of LSD as advantageous biomarkers of success in playing the game of handball. Higher measures of LSD, according to Srhoj, et al (2002) are of utmost importance because they could facilitate and enhance shooting and defensive effectiveness of players. In the AVB, the superiority of the above average players may, in part, be explained by the impact of training process on the muscle tissue increase (Grgantov et al, 2006). This is further reflected in the significantly higher values recorded by the above average players in both the muscle mass, fat free mass and some skeletal transverse measures. It could be conjectured, therefore, that the above average players may have had more and perhaps, better training schedule and routines than the average players.

It is obvious also that there were no significant differences in almost all the variables assessing subcutaneous fatty tissue (SFT) and some body composition variables (\%BF, BMI, and Somatotype) among junior male handball players. Cavala et al (2008) also reported no significant difference in most of the subcutaneous fatty tissue (SFT) variables between the groups of playing quality or proficiency. In that case, the junior players at 
Differences in Body Anthropometry between Competitively efficient and less Efficient Junior male Handball Players

both levels of performance were relatively homogenous in these body anthropometry variables. Some authors (Boracznski \& Urniaz, 2008; Duthie et al, 2006; DeRidder, 2003) have shown that excessive SFT in athletes, particularly \%BF, will exert unfavourable effect on performance. In this case, however, the above average players seem to possess higher adipose tissue, although not significantly different from the value recorded for the average players. For example, the expectation, perhaps, was that the $\%$ fat mass of above average players would be considerably lower than that of the average players.

Generally, the significant superiority of the above average players in most of the body anthropometry measures may have resulted from the process of selection more than training or any other technical input. Tomkinson and Olds (2002) opined that body type and success of athletes may have evolved as a result of environmental and genetic traits. Rakovac and Colleagues (2011) supported this view, stating that success in a given sport is the result of a combination of heredity, training and nutrition, as well as environmental and socio-cultural influences. As such, players who are endowed and who have been able to adapt to identified anthropometric insufficiency by compensating with the development of appropriate skills to specific demands of a sport during training will most likely be selected by coaches.

Finally, the similarities and differences in obtained results seem to support the assertion (Grgantov et al, 2006; Young, et al, 2005) that comparisons between groups that are substantially different in performance level can be misleading. This is because they tend to overstate the importance of physical qualities towards playing success. Tsolakis and Vagueas (2010) hold the view that classical anthropometric attributes must be seen and treated as simple descriptors rather than determinants of playing quality or efficiency. A better picture of players with superior body anthropometry and playing efficiency would be better determined if these attributes are combined with other performance parameters like motor ability, technical skills and tactical knowledge (Till, K. et al, 2011). The non - assessment of motor ability, technical and 
tactical skills and other determinants of playing success is a limitation in the present study.

\section{Conclusion}

The results of this study have shown conclusively that the above average players were significantly differentiated as possessing superior anthropometric characteristics. In specific terms, the above average players obtained statistically significant differences in LSD, AVB, and in some TSD measures. These may have obviously accorded significant performance advantage to the above average players. The junior male players at both levels of performance were relatively homogenous in the SFT and some body composition (\%BF, BMI and Somatotype) measures. These results, if disseminated, will provide relevant research based information/data about junior male handball players considering the paucity of such data in Nigeria. Data obtained from this study could also satisfy the needs of coaches, physical educators, athletic trainers and others for empirical based information about player characteristics necessary to detect and select potential players for training and development. It will also help to provide information necessary to evaluate the progress of players from one age level to another with a view to a better development of youth sports in general and handball in particular.

\section{References}

Adodo, S. M. (2014). Anthropometric characteristics and motor abilities of Nigerian junior male handball players. Unpublished doctoral dissertation, University of Benin, Benin City, Nigeria.

Boracynski, T. \& Urniaz, J. (2008). Changes in aerobic and anaerobic power indices in elite handball players following a 4 - week general fitness mesocycle. Journal of Human Kinetics, 19, 131 - 140

Buchheit, M., Laursen, P. B., Kuhnle, J., Ruch, D., Renand, C., \& Ahmaidu, S. (2009). Game-based training in young elite 
Differences in Body Anthropometry between Competitively efficient and less Efficient Junior male Handball Players

handball players. International Journal of Sports Medicine, 30, $251-258$.

Cavala, M., Rogulj, N., Srhoj, V., Srhoj, L. \& Katic, R. (2008). Biomotor structures in elite female handball players according to performance. Collegiums Anthropologicium, 32(1), $231-239$.

Cook, J. L., Kiss, Z. S., Kahn, K. M., Purdan, C. R., \& Webster, K. E. (2004). Anthropometry, physical performance and ultra sound patellar tendon abnormality in elite junior basketball players: A cross - sectional study. British Journal of Sports Medicine, 38, 206 - 209.

Dauda, Y. (2010). President's remark. Programme for the National under 18 and 21 handball boys and girls championship. Minna, $31^{\text {st }}$ July $-7^{\text {th }}$ August.

DeRidder, J. H. (2003). Nigeria All Africa Games Research Project (NAAGReP): Anthropometry Accreditation Course (Level 2): $24^{\text {th }}-27^{\text {th }}$ September.

Duncan, M. J., Woodfield, L. \& ai-Nakeeb, Y. (2006). Anthropometric and physiological characteristics of junior elite volleyball players. British Journal of Sports Medicine, 40, 649-651. Retrieved October 25, 2010 from http://bjsm.bmj.com

Duthie, G. M., Pyne, D. B., Hopkins, W. G., Livingstone, S. \& Hooper, S. L. (2006). Anthropology profile of elite rugby players: Qualifying changes in lean mass. British Journal of Sports Medicine, 40, 202-207

Elferink - Gemser, M., Visscher, C., Lemmink, K. \& Mulder, T. (2004). Relation between multi - dimensional performance characteristics and level of performance in talented youth field hockey players. Journal of Sports Science, 22, 1053 - 103.

Gabbett, T. J., Georgieff, B. \& Domrow, H. (2007). The use of physiological, anthropometric and skill data to predict selection in a talent identified junior volleyball squad. Journal of Sports Science, 25, 1337 - 1344.

Granados, C., Izquierdo, M., Ibanez, J., Bonnabau, H., \& Gorostiaga, E. M. (2007). Differences in physical

16 A Journal of the Department of Health, Physical Education and Recreation 
fitness and throwing velocity among elite and amateur female handball players. International Journal of Sports Medicine, 28(10), 860-867.

Gorostiaga, E., Granados, C., Ibanez, J., Gonzalez-Badillo, T. \& Izquierdo, M. (2006). Effects of an entire season on physical fitness changes in elite male handball players. Medicine and Science in Sports and Exercise, 38(2), 357-366.

Grgantov, Z., Katic, R. \& Jankovic, V. (2006). Morphological characteristics, technical and situation efficacy of young female volleyball players. Collegiums Anthropologicum, 30(1), 87 - 96.

Hasan, A. A., Rahaman, J. A., Cable, al. T. \& Reilly, T. (2007). Anthropometric profile of elite male handball players in Asia. Biology of Sports, 24(1), 3 - 12.

Handball Federation of Nigeria (HFN, 2000). Programme of events for Malta Guinness National handball League Championship, Owerri, 17 - 27 May.

Hopkins, W. G. (2000). Measures of reliability in sports medicine and science. Sports Medicine, 30,1-15.

Ingebrigsten, J. \& Jeffery, T. (2012). The relationship between speed, strength and jumpingabilities in elite junior handball players. Serbian Journal of Sports Science, 6(3), $83-88$.

Janssens, M., Van-Renterghen, B., Bourgeois, J., \& Vrijens, J. (2010). Physical fitness and specific motor performance of young soccer players aged $11-12$ years. Journal of Sports Science, 16, $434-435$

Marfell-Jones, M. (2003). Guidelines for athlete assessment in New Zealand sport: Kinanthropometric assessment. Retrieved on $15^{\text {th }}$ October 2010 from http://homepages:hug.co.nz/rip/anthropometry/

Mohamed, H., Vaeyens, R., Matthys, S., Multael, M., Lefevre, J., Lenoir, M., \& Philippaerst, R. (2009). Anthropometric and performance measures for the development of a 
Differences in Body Anthropometry between Competitively efficient and less Efficient Junior male Handball Players

talent detection and identification model in youth handball. Journal of Sports Sciences, 27(3), 257 - 266.

Nicolaire, A. H., Correa, U. C., \& Bohme, M. T. (2010). Anthropometric and motor skills in talent selection and development in indoor soccer. Perceptual and Motor Skills, 110(3), $916-930$.

Rakovac, M., Smoljanovic, T., Bojanic, I., Hannafin, J. O., Hren, D., \& Thomas, P. (2011). Body size changes in elite junior rowers: 1997 - 2007. Collegiums Anthropologicum, 35 (1), $127-131$.

Roschel, H., Baptista, N., Monteiro, R., Bertuzzi, R. C., Barroso, R., Loture, I., Ugrinowitsch, C., Tridoli, V., \& Franchini, E. (2009). Association between neuromuscular tests and kumite performance on the Brazillian karate national team. Journal of Sports Science and Medicine, 8(CSSS 13), $20-24$.

Srhoj, V., Marinovic, M. \& Rogulj, N. (2002). Position specific morphological characteristics of top level male handball players. Collegiums Anthropologicum, 1, 219 - 227.

Taborsky, F. (2007). The body height and top team handball players. EHF web periodicals, September. Retrieved October $15^{\text {th }}, 2010$ from http://activities.eurohandball.com on

Till, K., Cobley, S., \& O’ Hara, J., Brightmore, A., Cooke, C. \& Chapman, C (2014). Using anthropometric and performance characteristics to predict selection in junior UK Rugby League Players. Journal of Science and Medicine in Sports, $\quad$ 14(3), 264 - 269.

Tomkinson, G. R. S., \& Olds, T. S. (2002). Talent identification: The brave new world. Proceedings of 2002 KNUPE International Symposium, 21(1), 85 - 102.

Tsolakis, C., \& Vaqueas, G. (2010). Anthropometric, physiological and performance characteristics of elite and sub - elite fencers. Journal of Human Kinetics, 23, 89 - 95.

Young, W. B., Newton, R. U. Doyle T. L. (2005). Physiological and anthropometric characteristics of starters and non starters and playing positions in elite Australian Rules

18 A Journal of the Department of Health, Physical Education and Recreation 
football: a case study. Journal of Science \& Medicine in Sport, 8, 335 - 345 .

Zapartidis, I., Tonganidis, T., Vareltzis, I., Christedoulidis, T., Kororos, P. \& Skoufas, D. (2009). Profile of young female handball players by playing position. Serbian Journal of Sports Science, 3(1-4), 53 - 62. Retrieved October 14, 2010 from http://www.sjss.sportsacademy.edu on. 